\title{
La dimensión literaria de las Cartas Anuas de América, siglo XVII
}

\author{
ROXANA GARDES DE FERNÁNDEZ \\ Universidad Católica Argentina \\ roxana_gardes_de_fernandez@hotmail.com
}

Recibido: 30/10/2021 - Aceptado: 15/11/2021

DOI: https://doi.org/10.46553/LET.84.2021.p37-57

Resumen: Intentamos -en este estudio- analizar las Cartas como textos de una complejidad expresiva que expone una trayectoria figurativa novedosa -desde las preceptivas subyacentes- en la configuración de mundos de América. Esto supone articular un instrumento metodológico desde un paradigma teórico entre la fenomenología y la hermenéutica con algunas revisiones e integraciones de enfoques semiológicos y retóricos. Desde el eje fenomenológico-hermenéutico diferenciamos referencia / significado/ sentido. Aislamos procesos figurales del texto en la configuración semántica intensional/extensional.

Palabras clave: Cartas Anuas - jesuitas - fenomenología - siglo XVII

\section{The literary dimension of the Cartas Anuas of America, 17th Century}

Abstract: We try -in this study- to analyze the Letters as texts of an expressive complexity that exposes a new figurative trajectory -from the underlying preceptives- in the configuration of worlds of America. This implies articulating a methodological instrument from a theoretical paradigm between phenomenology and hermeneutics with some revisions and integrations of semiological and rhetorical approaches. From the phenomenological-hermeneutical axis we differentiate reference / meaning / sense. We isolate figurative processes from the text in the intensional / extensional semantic configuration.

Keywords: Cartas Anuas - Jesuits - Phenomenology - XVII Century

La acción de los padres jesuitas ha sido fundante de espacios culturales en el Río de la Plata. No obstante, las Cartas Anuas, informes testimoniales y fenómeno central de esta acción educativa y evangelizadora es un objeto inexistente para el conjunto de investigaciones emprendidas en el marco de las disciplinas de la cultura (humanidades o ciencias sociales). Objeto marginado de los estudios literarios -que, en cambio, incluyen las crónicas y diarios de viaje- solo considerado fuente por algunos historiadores de la orden y del accionar misional en América. Esos estudios -como las historias de Pedro Lozano- desde la misma visión y ante la imposibilidad de aislar el objeto, se convierten en paráfrasis de algunos aspectos o elementos para la argumentación del misionar evangelizador 
Intentamos -en este estudio- analizar las Cartas como textos de una complejidad expresiva que expone una trayectoria figurativa novedosa -desde las preceptivas subyacentes- en la configuración de mundos de América. Esto supuso articular un instrumento metodológico desde un paradigma teórico entre la fenomenología y la hermenéutica con algunas revisiones e integraciones de enfoques semiológicos y retóricos. Desde el eje fenomenológico-hermenéutico diferenciamos referencia / significado/ sentido. Aislamos procesos figurales del texto en la configuración semántica intensional/extensional.

Desde este enfoque, la referencia: el objeto señalado se distingue del sentido; el agregado simbólico que a través de sucesivas "mímesis" o actos de figuración lo significan. El sentido es inmanente al discurso, la referencia expresa el movimiento en que el lenguaje se trasciende a sí mismo. En esta dialéctica se expresa la relación entre lenguaje y condición ontológica del ser en el mundo, la situación del que escribe, situación enmarcada en sistemas descriptivos de mundo. Aislamos así un proceso complejo desde una serie de prefiguraciones: desde las de los textos gnómicos del cristianismo, a las reflexiones en las preceptivas del humanismo acerca de la historiografía y de la poética hasta los principios de la retórica clásica.

Delimitamos un corpus de estudio en torno a un espacio del Virreinato del Río de La Plata. Consideramos: Cartas Anuas de la Provincia del Paraguay, Chile y Tucumán de la Compañía de Jesús-1615-1637 (ordenadas por el Padre Lehonardt para la colección dirigida por Emilio Ravignani) en Documentos para Historia Argentina. Buenos Aires. Peuser. 1929. Tomo XX. Y Cartas Anuas de la Provincia Jesuítica del Paraguay 16321634 con Introducción de Ernesto J.A. Maeder. Buenos Aires. Academia Nacional de la Historia. 1990

Cada padre jesuita en su percepción /interpretación de América se desplaza hacia el eje intersubjetivo de la tradición del mundo cristiano medieval, los sistemas descriptivos de las preceptivas del humanismo renacentista.

La escritura es un acto constitutivo de la orden, confirmador y continuador de la misma en un espacio geográfico desde Indias a Roma y Europa. La Carta es una acción dentro del proceso de evangelización: un eje de la estructura jerárquica reglamentada.

El ser comprensible de este nuevo mundo adviene por medio de un estatuto perceptivo-constructivo sui generis en función del cual "la realidad" a través del lenguaje adquiere la forma de texto.

\section{La historiografía en los siglos XVI y XVII. La ambigüedad formal}

El esquema de articulación de las crónicas de Indias se inserta en un margen de ambigüedad teórica acerca de lo que es "historiografía". En los Siglos XVI y XVII la historiografía se concebía de otra manera. Si desde la tradición medieval el discurso y la narración histórica no excluían ensoñaciones y fantasías, los comentaristas de los siglos XVI y XVII postulan una diferenciación de "lo verdadero" y "lo verosímil". En el Siglo XVI gran parte de la historiografía se sustenta en la formulación de "lo probable". 


\section{ROXANA GARDES DE FERNÁNDEZ}

En el marco del pensamiento histórico del Siglo XVI, el criterio de aceptación del discurso histórico es el de "verosimilitud". Este concepto de "verosimilitud" señala el rasgo distintivo de obras de creación en las que "la secuencia episódica obedece a una causalidad nítidamente estructurada". En una segunda acepción ${ }^{1}$ del concepto es la marca estructural de un relato en que se procura "evitar falsedades extremas, lo absurdo y otras inconsistencias."

Entonces, de acuerdo con el pensamiento renacentista la historicidad de un texto se fundamenta en la coherencia estructural y filosófica que la narración exhibe. Alonso López Pinciano en Philosophia antigua poética aclara el concepto de "verosímil" como se entendió en el Siglo XVI: "El objeto no es la mentira, que sería coincidir con la sofística, ni la historia, que sería tomar la materia al histórico; y no siendo historia porque toca fábulas, ni mentira porque toca historia, tiene por objeto el verosímil, que todo lo abarca."2 Por otra parte, en el marco de la ideología erasmista (Convivium fabulosum) -de amplia influencia en el pensamiento español de entonces- la verosimilitud se marca como exigencia de articulación de un relato que debía además exponer la verdad psicológica, la ingeniosidad de su composición, la sustancia filosófica y el respeto a la moral. Entonces, el discurso verosímil está modelado por las normas de un discurso que lo precede, o sea por un concepto de elocuencia y expresividad coherente que remite a codificaciones retóricas en una especie de formulación de segundo grado.

\section{El contexto retórico del discurso en la historiografía de los Siglos XVI y XVII}

Jean Badin (1566) en Methodus ad facilem historiarum cognitionem propone premisas para la labor historiográfica: 1) consulta del material bibliográfico; 2) estudio minucioso de la geografía, sobre todo en la etapa de elaborar hipótesis. Así, en esta utilización de nuevas fuentes, de un material sobre aspectos socio culturales que otorgan al investigador moderno nuevos recursos desde un criterio interdisciplinario de la historia; el texto se enriquece de connotaciones. No serán sólo páginas en lenguaje informativo, sino también un entramado en un sistema de relaciones que se ordenan, en parte, desde cánones de una retórica. El lenguaje se dimensiona literariamente. Podemos considerar la historiografía del humanismo italiano que tiene inmensa significación literaria, como se expone en la teoría literaria del Renacimiento.

La elocuencia es una preocupación central y las conceptualizaciones retóricas son base primordial de la labor del historiador humanista. La retórica, como tal, determinaba entonces aspectos eficaces de la investigación y el informe. En un sentido más concreto, las preocupaciones retóricas se percibían- en el pensamiento histórico de los

\footnotetext{
${ }^{1}$ Concepto explanado por William Nelson en: Fact or Fiction: The Dilemma of the Renaissance Storyteller. Cambridge. Harward University Press. 1973. P. 30

${ }^{2}$ Alonso López Pinciano: Philosophia antigua poética. Madrid. Consejo Superior de Investigaciones Científicas. 1953. P. 220.
} 
humanistas- como un impulso innovador que, lejos de obstruir, liberaba y esclarecía la percepción del pasado que exaltaba el humanismo histórico.

$\mathrm{Y}$ es que en la historiografía humanista las relaciones escuetas del Medioevo fueron reemplazadas por una estructura narrativa en la que el discurso se elevaba reiteradamente por encima del nivel denotativo, en una especie de figura que la retórica había deslindado en la figura de la "supraveritatem". Esto significa una amplitud semántica en la exposición informativa. En el marco de esa historiografía (como en Viri illustri), en las crónicas de Indias hay un propósito de cuidada elocuencia.

En síntesis, la historiografía del Siglo XVI en la utilización de las fuentes, en el estudio de las instituciones, especialmente de la actividad económica y de la topografía es una expresión de los preceptos de Jean Bodin y un exponente de los principios de los teóricos italiano. Entre los historiadores, Ambrosio Morales el español, radicado en Córdoba y mecenas del Inca Garcilaso. La cita de esos principios de Jean Bodin en su Discurso de la lengua castellana (1566) y en Las antigüedades de las ciudades de España (1575) resultan en muestras de una preocupación filológica.

Por otra parte, como ya señalamos la historiografía humanista del Renacimiento expone recursos de la retórica en la línea trazada por Lorenzo Valla en Elegantia latinae linguae, (1471) y por Leonardo Bruni en De interpretratione recta, (Storia fiorentina 1404/1439) que postulan dar rasgos artísticos a la narración. Las figuras enargia, illustratio, disgressio son los medios de "ornato" de la articulación narrativa.

Las crónicas de Indias una tipología diferenciada del discurso histórico.

En la "Crónica de Indias" también el historiador podía desplegar su imaginación como en los modelos clásicos. Después de la visita de Juan de Ovando al Consejo Real y Supremo de las Indias en 1569 se reprodujeron ordenanzas que prescribían los procedimientos historiográficos. Se puntualiza como normativa: 1) un registro más amplio de fuentes; 2) una minuciosidad narrativa. Estos dos aspectos caracterizan la tradición castellana en la investigación historiográfica. En 1571 se redactan ordenanzas para reglamentar las noticias que se darían: I. asuntos de tierra y de mar; II. naturales y morales, perpetuos y presentes; III. sobre los que pueda caer disposición de ley. Con respecto a la expresión en las crónicas de lo que se percibe y vivencia en América, Gonzalo Fernández de Oviedo se pregunta en su Historia general y natural de Indias (que relata hechos desde 1492 a 1549)

¿Cuál ingenio mortal sabrá comprehender tanta diversidad de lenguas, de hábitos e de costumbres en los hombres destas Indias? Tanta variedad de animales, así domésticos como salvajes e fieros. Tanta multitud inarrable de árboles copiosos de diversos géneros de fructas, y otros estériles, assí de aquellos que los indios cultivan, como de los que la natura de su propio oficio produce, sin ayuda de manos mortales. (Libro I, 32)

Y en estas crónicas de Indias se expone una fundamentación teológica desde postulados medievales y de la patrística en una forma renacentista. ${ }^{3}$ La escritura de las

\footnotetext{
${ }^{3}$ El padre Josép de Acosta en Historia Natural y Moral de las Indias (1590) da una fundamentación teológica y espiritualista, que el padre cuestiona desde el primer capítulo de su relación. Cuestiones
} 


\section{ROXANA GARDES DE FERNÁNDEZ}

Cartas Anuas se desarrolla como un hacer pragmático, pero conceptualizado en la retórica y en formulaciones teológicas y filosóficas. Expresa, como las crónicas, el anhelo de revelación. Pero en los Padres es también la búsqueda de confirmar el itinerario simbólico en el eje de la antigüedad clásica del cristianismo; y es, además, la necesidad de explicar ante el Padre General de la Compañía y el resto del mundo la espiritualidad en América. Es, en síntesis, un intento de lograr por la visión desde Europa de la cultura americana. En las Cartas las interpolaciones legendarias encierran un testimonio cultural. Se incluyen a través de interpretaciones - refiguraciones imaginativas, el pensamiento y el sentir del indígena. A través de las Cartas se desvela una compleja realidad histórico-social- una intrahistoria aún vigente en muchos espacios de Hispanoamérica.

\section{El referente América}

Aislamos el referente y el sentido de América en el marco semántico de la situación social político-económica de España. Hay paz interna desde la época de los Reyes Católicos y hasta 1640, pero se producen los disturbios de las comunidades entre $1520 \mathrm{y}$ 1521. A pesar de esto, hay prosperidad en España hasta 1570. La agricultura y la ganadería se desarrollan bien determinando el ascenso de una categoría social: la de los labradores ricos, que se transforman en hidalgos y hasta en caballeros. Los labradores tienen un mediano pasar. Por debajo de los labradores están los campesinos.

La crisis se da después de esta fase de expansión en el Siglo XVI y se percibe desde 1570/1580 a través de una Encuesta de Terreno: "Las relaciones topográficas", llevadas a cabo por orden de Felipe II. Hay desequilibrio por la revolución de los precios que se multiplican por cuatro a causa los metales llegados de América. Se producen las bancarrotas de 1575, 1597 y 1607. Disminuye la producción del campo. Los banqueros genoveses, dueños de la mayor cantidad de dinero, se retiran. En fin, la España de fines del Siglo XVI atraviesa entre los años 1596 y 1602 una grave crisis. "La peste baja desde Castilla y el hambre sube desde Andalucía". En1583, un segundo "Índice General", el de Quiroga, informa sobre esta situación. Hay conciencia de crisis y las Cortes permanecen reunidas casi de manera continua analizando medidas posibles. Y, por otra parte, se crean juntas para salvar a España.

Desde diversos enfoques, por ejemplo, en el análisis de los arbitristas expuesto en el Memorial de Marín Gonzalo de Colorigo, el descubrimiento de América trastocó el modo de vida de España. Se marcan las consecuencias: el alza de precios; la entrada de metales preciosos que limita los centros financieros, el abandono de los sectores de productividad y la ociosidad. Así, los españoles al recibir el "maná americano" se desentienden de las fuentes de riqueza propias y no se desarrollan las industrias. Hay

aristotélicas y platónicas ponen en tela de juicio su discurso. Y es que los mecanismos expositivos pueden ser renacentistas, pero el registro de sus temas es fiel a los postulados de la historiografía medieval y la patrística. Hay como una incertidumbre conceptual. 
corrupción de costumbres, vicios, ociosidad. Se juzga que los problemas económicos en la España del Siglo XVII son causados por la importación de la plata americana. Los pensadores más lúcidos como Quevedo en Un Heráclito Cristiano o Manuel Sarmiento de Mendoza en Milicia evangélica para contrarrestar la ideología de los gentiles conquistar almas, derribar la humana prudencia, desterrar la avaricia de ministros, señalan el oro o la riqueza como causa de la pérdida de valores.

En 1598 muere el austero Felipe II. Se produce un cambio de atmósfera. Felipe III sólo piensa en diversión e instala un carnaval en la corte. Después de su casamiento con Margarita de Austria traslada la corte a Valladolid, a la Villa Pisuerga. Hay una tendencia a vivir de las rentas o adquirir un oficio o cargo público. La situación económica es de pobreza, corrupción, despoblamiento, falta de dedicación al trabajo. Si la situación económico-social de Europa es un impulso para la Conquista material se Indias, es también base del itinerario implícito de la acción jesuítica: hacia la Conquista espiritual.

En el marco del problema económico de España, las Indias son un espacio para comerciar y un centro de posibilidades para el desempeño de letrados que substituyen a militares y a nobles en la Administración y en los Consejos de la Monarquía española. Desde esa significación, las Indias (América) es el lugar de promoción social y adquisición de riquezas.

En el aspecto sociocultural la Universidad de Alcalá de Henares es en el Siglo XVI un centro de cultura humanística en el marco de reflexiones filosófico- teológicas bajo la impronta del pensamiento religioso de Erasmo. Francisco Jiménez de Cisneros, Profesor de la reina, Arzobispo de Toledo y Regente de Castilla, fundó en 1506 esta Universidad que compartió con la Universidad de Salamanca el monopolio de los estudios hispánicos. En la Universidad de Alcalá se crearon las cátedras de Gramática latina, Retórica, Griego, Hebreo, Filosofía. ${ }^{4}$ Ahí, en Alcalá, Diego de Boroa - 1585/ 1657-autor de las Cartas que estudiamos- se licenció en Filosofía en 1585. Mientras Francisco de Quevedo -1580/1645, educado por los jesuitas- también frecuentó las aulas de la Universidad de Alcalá entre 1596 y 1600. Adquirió su saber en filosofía, lenguas clásicas, francés, italiano. Formación que completó con estudios literarios y de teología. Ese contexto cultural influyó en los viajeros que llegaron a América y en los hijos, mestizos americanos. El Inca Garcilaso de la Vega -1539/1616- en 1560 se trasladó a España y, si en los primeros años actuó como soldado por España, se dedicó luego a la traducción de los Diálogos de amor de León Hebreo y -desde sus residencias entre Montilla, Madrid y Córdoba- escribió para exponer la realidad americana en La Florida del Inca -1605 y en los Comentarios Reales de los Incas - 1609. Contó con el estímulo del padre jesuita Juan de Pineda, amigo de Quevedo y otro jesuita: Francisco de Castro

\footnotetext{
${ }^{4}$ Se llevó a cabo la impresión de La Biblia poliglota por un estudio de los códices bíblicos antiguos, realizado durante quince años por los filólogos: Antonio de Nebrija, López de Zúñiga, Hernán Núñez, Demetrio Lucas y los judíos conversos Alfonso de Zamora, Alfonso de Alcalá, Pablo Coronel. Esta tarea, apoyada por el Papa León X, se concretó por el impresor Arnaldo Guillén de Brocar en la edición de 1517.
} 


\section{ROXANA GARDES DE FERNÁNDEZ}

le dedicó "al Inca peruano clarísimo" su obra: De arte Rethorica, dialogi quatuor, editada en Córdoba en 1611.

\section{Desde el referente al sentido en configuraciones del sistema literario.}

Si bien hemos aislado desde el sistema descriptivo de la historiografía, la situación de España en el Siglo XVI, intentamos enfocar este referente desde las proyecciones propias de las configuraciones literarias de esa etapa.

Proponemos un diagrama desde el mundo imaginario del Siglo de Oro. La reflexión de Miguel de Cervantes, su lúcida crítica a la España en decadencia, culmina en metáforas. Cervantes puede percibir a Indias desde otros lenguajes en la situación socioeconómica de crisis política y social de la España del Siglo XVII y en la revisión ideológica de la Contrarreforma.

En la situación crítica hay Hidalgos que se movilizan para servir a España por la búsqueda de un nuevo ser y hacia un nuevo destino. Cervantes crea sobre el referente de esa búsqueda la metáfora de El Ingenioso Hidalgo Don Quijote de la Mancha. ${ }^{5}$. Consideremos que a fines del Siglo XVI se produce una reflexión crítica sobre géneros y formas literarias. ${ }^{6}$ Se delinea una forma que desarticula la distancia entre historiografía y ficción, una especie de épica enriquecida: la novela. Una manifestación que agrega a la epopeya renacentista el trasfondo de la realidad histórica. Como ya señalamos, con Felipe III la corte en la Villa de Pisuerga se convierte en un centro de festejos. Allí residen temporariamente, Cervantes, Quevedo, López de Úbeda. Y la experiencia de estas fiestas palaciegas se expresa en la Segunda Parte de El Quijote, en el relato de las vivencias de los duques. La prosperidad propia de la primera mitad, del siglo XVI, el buen estado de la agricultura y la ganadería, son referentes para figuraciones de la Primera Parte -de 1605. La Mancha se describe en la prosperidad de una época: entre 1570 y 1600. Así desde la reflexión crítica sobre la situación de España, desde ese referente se significan, como en contraposición, las figuras de las dos partes. La prosperidad de La Mancha en la Primera Parte y los labradores ricos como clase social en pleno ascenso. Los labradores acumulan riquezas y se transforman en hidalgos y hasta en caballeros. Hay luego una tendencia a vivir de las rentas. Sobre esta base se configura el caballero del verde gabán -de la Segunda Parte. Cervantes crea, en diversidad de figuras y a través de características precisas, como en un mosaico testimonial, toda la estructura social de la época: los campesinos y sus mujeres, analfabetos, pero poseedores de sabiduría popular y un viejo cristianismo heredado. En el sistema descriptivo de ese mundo imaginario, "las armas son para la paz y las letras para la justicia”. La valoración de las letras (I. Capítulos XXXIX y XLII) apunta a un

\footnotetext{
${ }^{5}$ Miguel de Cervantes Saavedra: El ingenioso hidalgo Don Quijote de la Mancha. Buenos Aires Kapelusz. Colección GOLU. 1973. Tomos I y II).

${ }^{6}$ Sánchez de las Brozas: Organum dialecticum et rhetoricum 1579; López Pinciano: Philosophia antigua poética-1590; Jiménez Patón: Elocuencia española en arte-1604/1621; Correas: Arte de la lengua española castellana (1626); Baltasar Gracián: Agudeza y arte de ingenio- 1642.
} 
particular significado agregado al referente. El poder se ve como una propuesta en la que pueden participar letrados, expertos en leyes, juristas. Las figuraciones literarias se articulan sobre las prefiguraciones acerca del actuar de los nobles. La casa de los duques se instituye como una especie de casa de placer, donde los hombres del pueblo común como Quijote y Sancho son objeto de burla, instrumento de diversión (II. Capítulo VI). Hay figuraciones que exponen aspectos de la ideología tridentina: la relación entre la iglesia y el entorno social: el canónigo que habla de los problemas literarios al final de la Primera Parte, los frailes benitos, los sacerdotes que acompañan al muerto, los que participan en rogativas y posesiones, (I, Capítulos VIII, XIX, LII). El capellán del duque, el cura de las bodas de Camacho, el ermitaño (II. Capítulos III, XXI, XXIV). Cervantes configura sobre aspectos claves de la realidad social de España, con una actitud religiosa particular en la articulación de este sistema. ${ }^{7}$ El cura de la aldea va tras Don Quijote y no desempeña sus funciones. Se expresa, en cambio, que la iglesia es una posibilidad de ascender socialmente. Se alude a los beneficios, a la mucha renta, a las buenas comidas y a la vida no santa (I. Capítulos XII, XXVI, XIX y XXV). La edad de oro -ideal quijotesco- resume los valores como una búsqueda de lo que falta: la justicia en el Rey, en un momento en que la justicia era comprada. La paz, cuando España había guerreado con varios países, hasta la paz de Vervins, a fines del Siglo XVI. La configuración cervantina ironiza sobre las teorías desarrolladas en Salamanca acerca de la justicia de la guerra y contrapone a esas teorías un episodio burlesco (I.XVIII). El referente América se aísla en ese marco de refiguraciones sobre España. Desde esa perspectiva -como ya lo señalamos- América, las Indias, es una suma de posibilidades para adquirir riqueza, prestigio, promoción social. La dispositio narrativa de Cervantes que suma hilos o ejes narrativos, cada uno correspondiente a un itinerario vital, a un destino, dispone de puntos de enlaces, centros de encuentro y de cruces definitorios -de anagnóresis: desvelamiento de identidades. Uno de esos centros es la venta, que en el estrato elevado del relato es el castillo de Don Quijote. A la venta donde están Don Quijote y Sancho llega un cautivo con una mora. Se hospeda allí y narra su historia. Historia que Cervantes configura sobre sus propias vivencias como soldado en Lepanto y su cautiverio padecido en Argel durante cinco años. El cautivo relata su experiencia desde el momento en que su padre, en las montañas de León, decidió dividir su hacienda en cuatro partes para repartirla entre sus tres hijos conservando una para sí. La condición que impuso a sus hijos fue que eligieran ejercicio y, como consejo, les recuerda el refrán: "iglesia o mar o casa real “. Lo que significa una carrera religiosa, o navegar siguiendo el arte de la mercancía o entrar a servir a los reyes. Así, el padre expresa su deseo de que uno siguiese las letras, otro la mercancía y otro sirviese al rey en la guerra. El cautivo cuentaque su elección fue la guerra y después de una carrera exitosa, llegó a ser capitán de infantería. Pero en una jornada feliz en que habían vencido a los turcos (la batalla de Lepanto en 1571); él quedó prisionero de Uchalí- Uly Alí. Relata su cautiverio en Argel y cómo fue liberado por

\footnotetext{
${ }^{7}$ Sancho y Quijote no entran en las iglesias, no se oyen las campanas de las aldeas por las que pasan. Los hombres de iglesia no se ocupan del trabajo pastoral.
} 


\section{RoXANa GaRdeS DE Fernández}

acción de una morisca que se había hecho cristiana y quería emigrar a tierra de cristianos. Así, logró regresar a España. Después que el cautivo terminó su relato llegó a la venta un oidor con su séquito. Y el cautivo creyó reconocer en esta "figura tan principal", a su hermano. Supo luego, por unos de los criados, que el oidor era Juan Pérez de Viedma, de un lugar de las montañas de León “[...] se acabó de confirmar que aquél era su hermano que había seguido las letras [...] iba proveído por oidor a las Indias en la Audiencia de México y que era muy rico [...]". El cura se ofreció para comunicar al oidor la experiencia y la situación de pobreza del hermano cautivo, sin decir que estaba allí. El relato del cura conmovió profundamente al oidor. Recordó la angustia del padre- que aún vivía - por desconocer el destino de ese hijo mayor. Relató que el otro hermano estaba en América:

[...] Mi menor hermano está en el Pirú, tan rico que con lo que ha enviado a mi padre y a mí ha satisfecho muy bien la parte que él se llevó, y aún dado a las manos de mi padre con que poder hartar su liberalidad natural y yo, ansímesmo, he podido con más decencia y autoridad tratarme en mis estudios, y llegar al puesto en que me veo [...] (I. XLII. 516)

En la magistral articulación del relato, los dos hermanos se encuentran: “[...] acudió el capitán a abrazar a su hermano [...]" y la familia enriquecida con los recursos de América podrá socorrer a quien se empobreció al extremo en la guerra y el cautiverio. (I, Capítulos XXXIX, XL, XLI y XLII. 474-518). El Licenciado en Leyes irá a las Indias como oidor de la Audiencia de México. ${ }^{8}$

Veamos otra configuración del referente América. La de Francisco de Quevedo (1580-1645) ${ }^{9}$ que vivió la corrupción y pobreza en España a finales del Siglo XVI. Entre sus obras y las que se han clasificado como "Satírico- morales", 10 La Fortuna con seso y la hora de todos, "Fantasía moral"- de 1635- configura a América en el marco de significaciones que, desde las visiones españolas del Siglo XVII, se agregan al referente. La sátira puede considerarse como un valioso documento histórico. Consideremos el resumen:

En un Olimpo incierto un Júpiter disconforme mandó que "vinieran los dioses a consejo". Llegan Marte, Baco, Saturno, Neptuno, Plutón, Venus, la Luna, el Sol, el dios Pan, Mercurio. Júpiter ordenó a Mercurio que trajese al Olimpo a la Fortuna. Esta llega con su rueda y lleva detrás a la Ocasión: "gallega, gótica, calva: con un solo mechón". Júpiter señala a la Fortuna los disparates y maldades que comete, pero la Fortuna responde que quienes se quejan de sus acciones no ven que detrás de ella va la Ocasión,

\footnotetext{
${ }^{8}$ El Licenciado en Leyes en Salamanca irá a las Indias como oidor de la Audiencia de México. En 1592 Castillo de Bobadilla señala esta preferencia en su Política para Corregidores. El referente Indias está atravesado por la experiencia del soldado cautivo en su miseria (el propio Miguel de Cervantes) y el comerciante enriquecido en las Indias. La riqueza de América es descripta por el Inca Garcilaso que, en esos años, transitaba los mismos espacios de España.

${ }^{9}$ Educado por padres jesuitas y amigo del Padre Juan de Pineda, estudió en la Universidad de Alcalá, como el Padre Diego de Boroa, autor de las Cartas. Quevedo entre 1596 y 1600 frecuentó las aulas de la Universidad adquiriendo conocimientos en lenguas clásicas, francés, italiano, filosofía. Luego, en Valladolid estudió teología.

${ }^{10}$ Francisco de Quevedo: Obras Completas. Madrid. Aguilar.1966. Prosa. Tomo I. Pp. 253-312.
} 
como criada y fregona que se ofrece a todos. La Ocasión señala como a pesar de que se ofrece a todos; los hombres siempre encuentran alguna razón para desecharla y postergar soluciones. Júpiter ordena a la Fortuna que "para satisfacción de las gentes, en una hora y en un día debían hallarse todos los hombres con lo que cada uno merecía." La Fortuna cumplirá la orden ese mismo día -20 de junio. Mueve su cuerda y mezcla todas las cosas para iniciar a las 4 de la tarde la acción de "dar a cada uno lo que merecía".

La Fortuna, acompañada de su nodriza la Ocasión, en una hora ilumina las mentes de los hombres para que adviertan el engaño, el mal encubierto en acciones de corrupción en distintos lugares del mundo. Va destrabando hechos de mentira y corrupción en distintos lugares. En Dinamarca descubre a los arbitristas proponiendo medidas arbitrios- para mejorar la situación económica. Llega la Hora y se descubre que son engaños tramados en beneficio propio. La Hora llega así para descubrir las falsedades, hacer saltar las máscaras tras las que actúan viejas celestinas, rufianes, busconas, los letrados, los aduladores de los ricos, los taberneros. La Hora desenmascara también la imagen engañosa de Italia, que de "imperial" sólo le quedaba el nombre; la situación engañosa del duque de Osuna en Nápoles, los robos de los Tártaros en Moscovia, la envidia que los reyes de Europa experimentan ante la grandeza de la monarquía de España. Y se descubre el tráfico que los holandeses tienen con las Indias de Portugal y el riesgo que esto supone para Lima, Potosí, Buenos Aires. La Hora los enfrenta a su pretensión de dominio, a su codicia. También se testimonia cómo el Príncipe de Orange corta con su tijera de trasquila, costas y golfos diagramando esas "cercenaduras del mundo" con las que se fabricó una corona. La Hora descubre esas trampas y hace saltar los engaños de los alquimistas; señala las fingidas declaraciones sobre los viajes a las Indiasla apariencia falsa de esas empresas, contraponiéndoles el motivo real de cada viaje a América: llevar oro a España. En el marco de ese relato en que la Hora va señalando la corrupción y la mentira y reorga-nizando moralmente las circunstancias, Quevedo incluye el testimonio de la actitud del habitante autóctono de América frente a la Conquista.

Relata que un navío holandés se refugia de una tormenta en un puerto de Chile. Puerto custodiado porque los indios de Chile "guardan belicosamente su libertad". Los navegantes holandeses, hombres de "sedición y robo", sedujeron a los indios por medio de un discurso engañoso: "vengo a ofrecer amistad"-dijo el holandés - y a su discurso agregó regalos: vino, butera, queso, espejos, sombreros, espadas y un largavista que causa la admiración extrema del indio. Pero "llegó la Hora" y el indio con clara lucidez advirtió el engaño. Señaló que los holandeses han podido observarlos con ese largavista:

Con este artificio espulgáis los elementos y os metéis de mogollón a reinar [...] Fuistes sujetos al Rey de España, y levantándoos con su patrimonio, os preciáis de rebeldes, [...] Ni es verdad que nosotros somos vuestra semejanza, porque, conservándonos en la Patria que nos dio la naturaleza defendemos lo que es nuestro [...] Pensáis que lleváis oro y plata y lleváis envidia de buen color y miseria preciosa.[...] Salid con término de dos horas de este puerto.[...]. (293) 


\section{ROXANA GARDES DE FERNÁNDEZ}

Cuando la Hora llegó a su fin los dioses vieron que durante ese lapso la Fortuna actuó con justicia y dejó de distribuir bienes, favores y tristeza de manera arbitraria. Las cosas se reorganizaron "como deberían ser y no como son". Pero los pobres y desafortunados, al ser ricos, se volvieron soberbios y corruptos y fue tal la confusión de todo que Júpiter dispuso:

la Fortuna encamine su rueda [...] y ocasione méritos en los cuerdos y castigo en los desatinados, [...] Todos reciban lo que les repartiere, que sus favores o desdenes por sí no son malos, pues, sufriendo éstos y despreciando aquéllos, son tan útiles los unos como los otros. Y aquél que recibe y hace culpa para sí lo que para sí toma, se queje de sí propio, y no de la Fortuna que lo da con indiferencia y sin malicia. (312)

\section{La dimensión literaria de las Cartas. Su expresividad poética}

\section{Singularidad de la escritura}

Las Cartas Anuas como las crónicas de Indias, por una articulación en variedad de estratos, establecen una potenciación expresiva de la historia. Desde nuestra hipótesis sobre la dimensión literaria de las Cartas Anuas indagamos los rasgos que caracterizan los géneros literarios. En el marco de las preceptivas literarias del humanismo renacentista sondeamos la diferenciación de "modos" según los "objetos" de la mímesis. Indagamos también la distinción en lo formal en la épica y, focalizamos la relación que en la preceptiva de tradición aristotélica es establece entre dianoia y mito o teología. Con relación a los modos diferenciados por "los objetos de la mímesis", el proceso figural de las Cartas se instala en los estadios superiores, los estadios considerados de "alta mimética" por los "objetos superiores" que figura. El primero corresponde a las citas e inserción en la escritura de las Cartas de expresiones de los evangelios y de otros fragmentos bíblicos configurando el espacio de trascendencia del mundo cristiano. El segundo estadio corresponde a la mímesis, figuraciones y relatos de las acciones de cristianos ejemplares, aún como mártires en la acción evangelizadora. ${ }^{11}$ El tercer estadio identifica a loa relatos de acciones de seres superiores a los demás hombres, circunstanciados en un mundo natural. Si en la tradición literaria son relatos de las acciones de los héroes de las epopeyas, en las Cartas los héroes son los padres en su acción evangelizadora. Un accionar sólo posibles por la fortaleza desde un extremado fervor, en situaciones de miseria y peligro, en itinerarios de misiones en travesías por un espacio geográfico extensísimo y selvático poblado de infieles. El informe de los padres al incluir el pensar y el actuar de los indígenas articula un cuarto estadio y es el que corresponde a los relatos del accionar de los hombres comunes. ${ }^{12}$ En los tres estadios superiores, los de "alta mimética" la preceptiva de tradición aristotélica distingue un argumento de base, un despliegue semántico [mito][teo]-lógico en el que se inserta

\footnotetext{
${ }^{11}$ En la Provincia Jesuítica del Paraguay la muerte del Padre Roque González por los infieles se relata en las Cartas como un ejemplo claro y presente del fervor religioso en la misión evangelizadora.

12 El quinto estadio que se denomina de "baja mimética" corresponde a seres inferiores en inteligencia y en poder. Es el propio de la comedia.
} 
como eje temático la exposición del pensar, la reflexión: un ideario o "dianoia". La base teológico-cristiana determina el contorno de la dianoia: el pensamiento jesuítico. Los dos aspectos se complementan en el discurso de las Cartas. El pensamiento de Santo Tomás, el de Francisco Suárez constituyen el campo semántico más amplio, en este relato épico. ${ }^{13} \mathrm{El}$ discurso alcanza la altura de una narrativa épica, en prosa oratoria porque es portadora de un mensaje para los habitantes del nuevo mundo y en segundo estrato para los lectores de Europa.

El objetivo es informar. La Octava Carta de 1615, que es la primera de la Provincia (fundada en 1607), informa sobre la extensión de dicha Provincia, el número de Misiones, la actividad en los seis colegios, el estado y acciones en las tres residencias, la acción doctrinal y educativa en las ocho reducciones. Los obstáculos y los logros. El autor, el Padre Pedro de Oñate, da testimonio así del fervor que sostiene los 134 misioneros en el esfuerzo de una tarea que exigía traslados constantes sin medios y sin caminos a través de un espacio extensísimo y selvático.

Las Cartas exponen la aceptación jesuita del indígena y la constatación por parte de los Padres de una intelección creativa originaria autóctona. A través del recurso retórico de la amplificación dan testimonio de creaciones por una intelección indígena; y esas creaciones se inscriben en el esquema de la cultura europea -en el eje del cristianismo. Un narrador, relator omnisciente, se adentra en los procesos mentales de los personajes, figuraciones que instauran duplicaciones interiores de sentires de pensamientos. Ante un relato que incorpora cartas, descripciones; en vez de preguntarnos (con Platón) ¿quién habla? instalamos la pregunta: ¿de quién son las percepciones, pensamientos, sentimientos que dan forma a ese mundo y a ese relato? Como señalamos nuestro enfoque es hermenéutico y advertimos la tensión ecuménica de la visión de los padres. Articulan su mundo y su accionar en un movimiento concéntrico que va incluyendo e integrando perspectivas. La enunciación enmarcada delinea un narrador que describe lo que piensan o sienten otros:

cundió tierra adentro la peste para auxiliar a aquellas ovejuelas y "fuese el Padre Gerónimo Porcel pues era la necesidad extrema ayudarlos. Partió muy a la ligera y aunque el rigor de los fríos y fuerza de las aguas le dieron bien en que padecer, no era todo nada en comparación del dolor agudo que traspasaba sus entrañas de ver la lastimosa presa que tenía como la peste en los cuerpos hecha ya el demonio en las almas. (Boroa, Carta 1632-1634, 163-164)

En estilo indirecto libre se expresan por la cenestesia interpretaciones de pensamiento, difuminan los límites. También en el agregado la visión, el pensar, el decir del indígena se funden en la visión, el pensar y el decir de los padres:

[...] El indio cuenta [...] que le refirieron todo lo que le había pasado en el Guayra [...] parece se querían acreditar con el indio para entrársele después con engaños como lo tiene de costumbre [...]" (Boroa, Carta 1632-1643, 203)

\footnotetext{
${ }^{13}$ En lo formal, la distinción por los objetos de imitación se corresponde con la oda, la épica, el drama. La oda canta la alabanza de la eternidad: el ideal; la épica celebra la historia: lo grandioso; el drama expone la vida: lo real.
} 


\section{RoXANa GaRdeS DE Fernández}

Se articulan el conocimiento de la tradición del cristianismo, el de la nueva realidad natural y sociopolítica y un poder expresivo particular que la misión requiere. En cada página el tema- se presenta como "un cristal de escaparate", importa lo que hay detrás. $\mathrm{Y}$ es que con relación a la diégesis el discurso de las Cartas es un discurso mixto. Habla el autor y hablan los seres que configura en su relato. ${ }^{14}$

\section{La expresividad poética de las Cartas}

Para indagar este aspecto nuestro enfoque teórico se inspira en la retórica clásica ${ }^{15}$ que abarca los tres aspectos de las figuraciones miméticas en la dimensión textual. Esto es la inventio, la dispositio y la elocutio. Así vemos que la escritura de las Cartas se inscribe en el eje de una producción y de una recepción prevista: Inventio/intelligio. Las apelaciones dirigidas al lector a través del vocativo: VP (Vuestra Paternidad) sugieren un hablante comprometido, un agregar énfasis al contenido, a la necesidad de comunicar. Los modos típicos de la arquitectura narrativa combinan la perspectiva de la visión autoral y la perspectiva de la acción. Se da, además una presentación de la acción de escritura. Se expone un sentir y un actuar misional sostenido. Representan el pensamiento cristiano y los obstáculos al accionar de los padres. Y si la elocutio debe lograr el deletare para el docere y el movere, y si en la inventio se señala el referente América; debe haber una transformación por la dispositio narrativa y sus artificios argumentativos para la figuración de ese objeto en el marco de valores compartidos. Porque, en efecto, la carta escrita por el padre Provincial de la Compañía está dirigida al Padre General de la Orden, entonces entre el emisor y el receptor hay solidaridad ética, pero esta solidaridad se sostiene en el grado de eficacia de las exposiciones sobre la tesis moral.

Nos interesa la dispositio, la articulación estructural de macro-componentes textuales, la estrategia de su orden y la expresividad estética del mismo. La "disgressio" que responde, en este caso, a la esencia de la inventio: vinculada con el proceso de "evangelización/inclusión" incorpora "loci” como "sedes argumentarum" (Quintialiano) o fuentes de esquemas argumentativos.

\footnotetext{
${ }^{14}$ Sócrates, según el Libro tercero de La República de Platón, hace la diferencia entre diégesis y mímesis y señala la combinación de las dos. Se tienen en cuenta los mundos que imitan: personas: superiores, iguales o inferiores. Y se distinguen modos. Así 1) en la representación temática autoral, habla el poeta; o, 2) hablan los personajes en la representación dramática interpersonal. Entre los dos polos entre los que se genera el poder evocativo del discurso verbal hay una tercera forma: 3) habla el poeta y los personajes. Así se da un discurso autoral, un discurso figural y un discurso mixto. La diégesis puede ser así, presentación autoral y representación (personificada de una acción).

${ }^{15}$ Si bien las reflexiones sobre la "elocutio"-figuras y tropos- propuestas en el marco de la neo-retórica del Siglo XX son sumamente útiles al investigador, consideramos que hay aspectos de expresividad para la comunicación en la inventio y en la dispositio. En 1569 se imprimió en Sevilla De Arte Rethórica libri tres, ex Cicerón et Quintiliano praecipu deprompti de Cipriano Suárez. Este libro que resume preceptos clásicos fue adoptado por la Compañía de Jesús, según se señala en la Ratio Studiorum de 1599.
} 
Por un proceso de transferencia de formas genéricas, las Cartas: relatos, informes, biografías, autobiografías, articulan una particular argumentación sobre el eje del idealismo cristiano.

En el marco de un discurso informativo, el logos narrativo excede las formas comunes del discurso histórico, amplía las visiones esquematizadas aceptadas como normativas en el discurso medieval. El discurso de las Cartas se articula sobre la base del discurso doctrinal- en el eje de su accionar de evangelización - incluye como prefiguraciones creencias que preceden, que se anticipan a esas percepciones del mundo nuevo y de sus habitantes: las Epístolas de San Pablo, las Homilías de San Juan Crisóstomo y de Gregorio Naceanceno (el gran orador), esos fragmentos de la patrística cosmogónica que actúan como eje ordenador aún de las fabulaciones del mundo nuevo. $^{16}$

\section{La enunciación en niveles o estratos}

La dispositio se articula en estratos o niveles. Cada uno aporta a la argumentación. El primer nivel corresponde a una alta mimética porque se traza en la dimensión de la doctrina cristiana e instala el eje de la solidaridad ética. Es un informe desde la tesis moral de la misión evangelizadora en la comunicación entre emisor y receptor. La elocutio expone este movimiento ascendente del lenguaje hacia el eje gnómico: hacia las fuentes. Así, se configura por la escritura el espacio simbólico del cristianismo instalando en la página, como testimonio, el texto de las escrituras y en latín. En este recurso de la página en la página, el espacio simbólico surge por actualizar en el pensamiento e inscribir en la página los conceptos de las autoridades de la Institución. El discurso remonta a la palabra fundadora en latín, redimensionando el romance. Consideremos el símil en la Novena Carta de 1616/1617 del Padre Pedro de Oñate. Al describir la situación social y señalar la acción de los padres informa que: "los españoles son estorbos a los indios para su salvación" refiere un

[...] castigo que nuestro señor ha hecho a esta ciudad por los agravios que les hacen a estos pobres naturales [...] Un caballero de esta ciudad hizo una entrada a indios con alguna gente de guerra y licencia del gobernador [todo lo atropello [trajo más de 200 personas de sus tierra donde estaban con sus parientes y como los cogió desapercibidos y ellos le vieron armado[...] sin pelear luego le dieron las manos y se le rindieron pero nuestro señor no tardó en mostrar lo que le había desagradado y ofendido semejante atrevimiento. Comenzó el cielo llover piedra y dos o tres aguaceros razonables de que creció el río que antes era muy pequeño que se hizo un gran mar tan furioso llevando por delante cuanto topaba y dando en las estancias se las llevaba de suerte, que, habiendo en una estancia iglesia, molino y otras cosas, ni una señal dejó del sitio [...] y así murieron más de 100 indios en este segundo diluvio. [...] que parece que se cumplió el castigo que profetizó David en el salmo 106: "Posuit et terram fructiferam in salsuginem a malitia inhabitantium in ea porque no contentándose nuestro señor de haber ejecutado el castigo que un poco antes había dicho por el mismo profeta posuit flumina in desertum et exitus aquarum in sitim, enviando dos meses antes tanta sequía 16 Juan Luis Vives en Disciplinis de 1531 dedicada a Juan III de Portugal comentaba: "Verdaderamente el
mundo ha sido abierto a la especie humana." 


\section{ROXANA GARDES DE FERNÁNDEZ}

que perecieron los sembrados y la tierra, envió el segundo castigo que fue tanto mayor $[\ldots](69-70)$

La transcripción de pasajes de los Salmos y de fragmentos de los Santos Evangelios que hacen presentes las enseñanzas de Cristo expone, actualizando en la página, el pensamiento cristiano guía de la misión: "nollentes intelligere ut bene agant et ceci cecis ducatum prestant faciat Deus ne in foream cadant". Paráfrasis de "Noluit (injustus) intelligere, ut bene ageret": ("No quiso comprender para obrar bien") este fragmento del Salmo XXXV,4 remite a una expresión de Jesucristo registrada por San Mateo: "Caecus autem, si exeo ducatum praestet, ambo in foream cadunt" ("Si el ciego guía al ciego los dos caen en el hoyo.”) (Mateo: XV, 14) En otro fragmento se parafrasea la expresión de San Juan en el Evangelio: "arbitrante se obsequium prestare Deo" (Cualquiera que os mate pensará que hace servicio a Dios") (XXVI, 2). Es decir hay alusiones constantes a ejemplos bíblicos y se argumenta con la transcripción de parábolas. Así la acción del enemigo expuesta por San Mateo como la siembra de la cizaña: "inimicus homo superseminauit cicaniam" ("Vino el enemigo y sembró la cizaña en medio del trigo") (XIII, 25) (Novena Carta, 10/ 61)

El segundo estrato que, desde las clasificaciones literarias, corresponde también a la alta mimética informa y testimonia sobre el accionar de los padres. La percepción de cada Padre es una visión desde sí mismo a través de la orden, a través del "misionar". Son héroes figuraciones de una dianoia sostenida en una trayectoria física llena de dificultades que se vencen por su fortaleza espiritual: "Estos padres [...] al fin de todo viven vida apostólica contentándose con lo que decía San Pablo: "habentes alimentas et quibus tagamur et" ("Teniendo con qué sustentarnos, y con qué cubrirnos, contentémonos con eso.”) (I. Timoteo, VI, 8) “[...] et tacentibis nobis pro nobis pugnat. Aei sea la gloria in eternum". Paráfrasis de "Dominus pugnabit pro vobis, et [...] tacebitis". ("El Señor pelea por vosotros aunque calléis") (Éxodo, XIV, 14 (Ib. PP. 9/61)

La narración articula su argumentación por la inclusión de voces: La Octava Carta del Padre Provincial Pedro de Oñate de 1615 incluye las de los padres Roque González y José Cataldino. Pero además José Cataldino incluye un suplemento de la Carta Anua del año anterior, la de 1614. La Novena Carta del Padre Provincial Pedro de Oñate de 1616, incluye las cartas de los Padres Pedro Romero, Diego de Boroa y Simón Maceta. La complejidad de esta enunciación en niveles es mayor cuando se expresan premoniciones de los padres. Así en la Carta de José Cataldino se expone como un dictado de conciencia que ordena al padre casar cristianamente a un indígena. Se explica que el indígena también recibió en sueños ese mandato por una voz superior. Veamos la complejidad de la enunciación en cuatro niveles y el nivel cuarto tiene a su vez tres estadios. Numeramos:

1) un nivel marco de "escritura ahora" que incluye 2): "[...] en la Annua pasada escribí (en estilo indirecto), 3) estando un padre en oración oyó: 4.1) que le decían 'casale'; se encontró con el cacique 4.2) (y este) dijo 'parece que me despertaba' 4.3) 'diciéndome:[...]" 
El esquema de articulación de enunciaciones dentro de enunciaciones, discursos en el discurso permite incluir aún las experiencias íntimas, los estados de conciencia de los padres y de los indios.

Por otra parte, en un ritmo particular en la narración por el recurso de la abreviación, muy propio de la epopeya; se dejan episodios incompletos y luego se retoman: "volvamos atrás en la narración [...]" (B 106). Las alusiones a la escritura como síntesis inciden en el ritmo: "Los anales pasados escribieron la furia y presteza increíble con que este espantoso torbellino asoló [...]" Se expone la acción de escribir y la búsqueda de coherencia: "Pero dejemos al Padre Nicolás y acudamos al Padre Ignacio Martínez [...]" (Boroa, Carrta 1632-1634, 109)

El relato en plural mayestático en una primera persona cambiante -pues cada Carta incluye otras- y en cada relato el autor expresa las modalidades semánticas. La existencial, ontológica al descubrir y dar evidencia; la modalidad epistémica desde distintos grados de conocimiento en amplitud, la factual: en un recorrido doble: desde una pre-figuración, configurar y refigurar. El hacer "ser" de una cultura para conocimiento de otros. Y, por la modalidad axiológica, otorga una valoración especial a la iniciación cristiana del indígena. La escritura es el espacio de una ontología: un lenguaje y una cultura que se incluyen. Desde el "dar alguna noticia [...] a la descripción topográfica "poner delante de los ojos" por una visión en movimiento concéntrico. En la Duodécima Carta- 1626/1627 Nicolás Mastrillo Durán relata su viaje. La inventio- en la dialéctica de culturas- delimita el objetivo: el intelligere por el receptor previsto.

[...] Porque toda la gloria de nuestra Provincia la deriva de la apostólica empresa que tiene por asunto, de sujetar al yugo del evangelio tantas bárbaras y fieras naciones para dar alguna noticia a las provincias de Europa del modo como esto se hace me ha parecido necesario describir en breve su sitio y disposición pudiéndolo hacer como testigo de vista por haberlas este año pasado visitado todas por la obligación de mi oficio $[\ldots]$

Los recursos caracterizados por las reflexiones que en el Renacimiento actualizaron la retórica son especialmente valorados por los escritores jesuitas. Vamos a detenernos en fragmentos de articulaciones magistrales de dos escritores: Nicolás Mastrillo Durán, el italiano de Nápoles y sin duda formado con los principios propuestos para la escritura de la historia por Lorenzo Valla en Elegantia latinae linguae, (1471) y Leonardo Bruni en De interpretratione recta, (Storia fiorentina 1404/1439). Según la retórica el discurso literario se caracteriza- desde Aristóteles- por rasgos que funcionan como "ornato". La literatura es caracterizada como "sermo ornatus" lo que requiere una desviación del lenguaje común y el uso de figuras de distintos niveles.

Veamos la descripción topográfica y su funcionamiento en la argumentación. Consideremos el ritmo del relato, en esa descripción del espacio. Podemos ver cómo por el ritmo se intensifica lo narrado. La progresión veloz de los hechos los destaca. A través de la "abreviación" (braquilogía) brevitatis formula, o frase abreviada; otras por epitrocasmo o un narrar como corriendo por la acumulación de verbos. 


\section{RoXANA GaRdeS DE FERNÁNDEZ}

Llamase la primera de estas provincias el Paraná, la segunda el Guayra, la tercera el Uruguay. [...] El grande río de La Plata se desagua en el océano por sesenta leguas de boca a 35 grados de altura para el mediodía: desde aquí enderezan los navíos su curso otras 60 leguas al poniente y en el fin de ellas topan con la ciudad de Buenos Aires asentadas sobre sus mismas riberas. De aquí se navega en barcos grandes para el norte perdiendo el nombre de río de la Plata y cobrando el de Paraná que le dan los naturales y significa pariente del mar, y a 80 leguas de distancia sobre un brazo que extiende sobre un lado está fundada la ciudad de Santa fe y prosiguiendo navegando otras ciento y veinte se encuentra la ciudad de las Corrientes así llamada porque en ella se junta con el río Paraguay que quiere decir río de plumas, así porque le pueblan innumerables pájaros de diversos colores, como porque los indios que moran en sus riberas se visten y engalanan de vistosa plumería.. Sobre este río a 60 leguas está situada la ciudad de la Asunción cabeza del Paraguay, volviendo a la ciudad donde se juntan estos dos ríos, llamase de las siete corrientes, porque al encontrarse se entremeten otras tantas no sin grande maravilla muy arrebatadas y furiosas, con otras siete como tablas de agua que corren tan sesgas porque su apacible movimiento apenan determinan los ojos para cuál parte siguen su camino con ser el mismo que el de las otras, y como dije interpuestas y trocadas entre sí. Ni es menos espanto lo que se ve también en esta junta, que aunque corren entrambos por una misma madre cada uno conserva por más de 30 leguas distintas y apartadas sus aguas con una como línea que los divide por el medio, parece que como desdeñándose el Paraná de mezclar sus aguas que son muy cristalinas y sutiles con las del Paraguay muy turbias y groseras. El uno y otro son de amenísimas y apacibles orillas pobladas por todas partes de muy frescas arboledas que encumbrándose al cielo nunca se desnudan del verdor de sus hojas que les conservan perpetuamente la humedad y fertilidad de la tierra, y entretejidas de hermosísimas flores exceden la variedad y belleza de los cuadros de Flandes". (262-264)

He subrayado sólo algunos verbos, para que se advierta la abreviación y el ritmo. El discurso muestra que el narrador, más allá de instalar el espacio en su magnificencia, busca un efecto: señalar las sugerencias imaginativas del habitante autóctono. La inclusión de las voces del lenguaje indígena: Paraná, Paraguay a través de las cuales el autor recoge y describe los elementos de una situación cultural y en presencia de un entorno natural articula la modalidad ontológica (que da existencia), la modalidad factual (la percepción, el dar cuenta) y la modalidad axiológica en la valoración del indio. Se logra veracidad expresiva del informe y se expone la capacidad creativa del habitante autóctono, su figurabilidad y simbolización poética de un entorno propio. En esta aclaración de significaciones -en el uso referencial del lenguaje- advertimos el rescate del material legendario y la exposición de los estadios elementales de mundos culturales originarios. Formas primigenias del pensamiento guaraní. Por otro lado, la expresividad poética en las imágenes visuales, en las imágenes de movimiento y en prosopopeyas propias del "locus amoenus" que nos recuerda a Garcilaso, Sannazaro, Horacio, Virgilio: “amenísimas y apacibles orillas pobladas [...] arboledas que encumbrándose al cielo nunca se desnudan del verdor de sus hojas". Otras expresiones de "animismo" suman al ornato "corrientes arrebatas y furiosas"; "como desdeñándose el Paraná de mezclar sus aguas que son muy cristalinas y sutiles con las del Paraguay muy turbias y groseras" "aguas sutiles // aguas groseras" El párrafo cierra con una comparación para la illustratio: "hermosísimas flores exceden la variedad y belleza de los cuadros de Flandes." La Carta de Nicolás Mastrillo Durán incluye una 
de Diego de Boroa donde informa sus acciones del año 1626. El trayecto de su viaje abarca desde Encarnación: Itapúa, Paraná al norte hasta el Guayra.

Veamos lo subrayado y lo marcado "en negrita".

Embarcámonos pues navegando río arriba en busca del salto. Este salto es la cosa más mentada y temida que hay en todas estas provincias, así por ser imposible el navegarle como por haberse perdido en él muchos españoles que por no conocer la furia del río fueron arrebatados desastradamente ( $\mathrm{y}$ aún cuentan que unos 40 españoles después de haber sujetado muchos indios de la provincia del Guayra se atrevieron con más de 30 balsas cargadas del despojo y se perdieron en este salto que no pareció más español ni balsa ni cosa ninguna) llegando pues poco a poco con mi gente hacia el salto comenzamos a experimentar la furia del agua, porque ya los indios no podían bogar, y un brazo de una corriente dio con mi balsa en unas peñas por donde se hizo pedazos una canoa de ella , y luego otra balsa se anegó y como fue cerca de unas peñas solamente se mojaron los padres que iban en ella [...] con que echando de ver que era temeridad navegar más adelante tomamos todos nuestro bordones y comenzamos a caminar a pie [...] porque en aquel paraje ni hay caballos ni fueran de provecho por ser aquel camino muy áspero [...] De este salto cuentan muchas fábulas .Una de ellas es que salta todo junto el Paraná por una canal y queda el salto tan lejos, que los hombres pueden navegar y pasar por debajo gozando de la sombra del agua; pero no es así, porque el río se despeña de un alto cerro de peñas que tiene como doce leguas de bajada, y es tanta la furia del agua que se quiebra por aquella muchedumbre de peñas, que son varias y de espantable figura, haciendo en infinitas partes varios canales encontrándose las unas con las otras con espantoso remolino haciendo en parte muchas pozos y juntándose las aguas en otras, y penetrando por debajo de las peñas parece que a veces parte de esta agua se hace invisible saliendo después con la misma furia de tal modo, que toda el agua en las dichas leguas no le parece sino una espuma de plata bruñida, que bañada del sol quita la vista de los ojos, y el ruido es tan grande que se suele oír a 3 y 4 leguas de allí. Cuando acaba de bajar toda esta agua aunque parece que anda sin peñas y en tierra llana con todo eso es muy peligroso el navegar por ella, porque aunque parece muy sosegada; muchas veces al día y aún cada hora se levanta un ruido extraordinario causado de algún oculto remolino porque el agua de repente bulle y salta algunas varas en alto, lo cual he visto y notado con particular cuidado y [aunque más bajo hay muchos remolinos muy peligrosos que los Indios que navegan por allí se han perdido muchas veces $],[\ldots]$

Consideremos en el relato la heroicidad de la empresa a través de expresiones de las modalidades ontológica y epistémica (subrayadas), en algunos casos la modalidad alética de conjetura (las expresiones en negrita que ponen en duda "lo que se cuenta"). Hay un texto primario- el eje de la Carta: el relato informativo de viajes, de la acción evangelizadora; y se agrega un texto secundario. Una disgressio o paremia ${ }^{17}$, este recurso por el que se expone "lo que cuentan", "lo que se fabula" instala ingeniosamente una página literaria. Si bien la descripción tiene particular importancia en la modalidad ontológica pues funciona para "demostrar", en la topografía se trata de "poner delante de los ojos del receptor el objeto descripto", en el relato de Boroa se

\footnotetext{
${ }^{17}$ Erasmo señala función paremiológica de "la digresión", "lo agregado". El pensador de gran influencia en ese centro del Humanismo que fue Alcalá de Henares enumera los alcances de la "paremia": "para persuadir, para filosofar, para adornar, para entender." (Convivium fabulosum)
} 


\section{RoXANA GaRdeS DE FERNÁNDEZ}

agrega la percepción y el agregado imaginario del habitante autóctono. Veamos el fragmento final con las comparaciones hiperbólicas (que subrayamos):

en esta parte del río se hallan pescados muchos y muy grandes como tiburones que son menester dos hombres para llevar uno y el Padre Antonio Ruiz me ha certificado haber visto un pescado tan grande como un buey y nadar medio cuerpo fuera del agua, y no es esto increíble, porque 3 días después de salir yo de las reducciones de el Guayra me escribieron que un pescado de estos había tragado un Indio entero que después le lanzó otra vez en la playa." (Duodécima Carta de 1626, 300-302)

En una Carta anterior (la Undécima - años 1618/1619 ${ }^{18}$ ) Diego de Boroa informa que los indios del pueblo de San Cristóbal, deseosos de una reducción, piden al Padre Pedro Romero que se los provea de un sacerdote. Y señala la causa usando el recurso de la etopeya: "movidos por el impulso del Espíritu Santo [...]" Relata que despachan una embajada de caciques principales con un indio muy elocuente que: "[...] hizo su oficio de embajador con razones tan fervorosas y eficaces que [...] hablaba por aquel órgano su ángel de la guarda [...]” (Boroa, 186)

Otro recurso propio de la literatura es esa especie de transferencia que aísla las palabras del mundo simbólico del indígena y abre un espacio de significaciones en otro campo semántico. Veamos "la imagen" en el campo semántico. Se relata cómo ha sido evaluada por los indígenas la acción de los padres: "han ganado el apellido de Tupanboyate que suena lo mismo que 'verdaderos siervos de Dios'. "Decretaron que se quedaran los de la Compañía a doctrinar a sus hijos [...]" y en estilo indirecto libre agrega lo que piensan y dicen los indios: "[...] porque son buenos padres y no nos hacen mal ninguno ni nos quitan nuestras mujeres [...]" (Boroa, Décima Carta- 1617, 157)

El recurso de la comparación en la elocutio de esa inventio desde la dialéctica de dos culturas funciona para intelligere al instalar en la expresión bíblica: "los indios son naturalmente de corazón esforzado, pero les falta el consejo [...] Ante los portugueses y sus malocas "[...] perdieron el ánimo y andaban como manada de ovejas descarriadas sin orden como aterrados de los ladridos de estos fieros mastines" (Boroa, Carta 16321634, 111) La comparación sitúa en el eje bíblico. Intuimos que en el receptor jesuita: el Padre General de la Compañía, que recibe el informe del Padre Provincial, se instala la figura del hacer misional, en el trasfondo de los símbolos bíblicos: el pastor/ las manadillas desvalidas/el lobo carnicero/temor y acechanza.

En síntesis, se revela la estrategia de un proceso particular de enunciación que incluye la trayectoria figurativa desde la Biblia. Los textos sagrados del cristianismo -fragmentos de epístolas, de homilías, de los salmos de los evangelios- citados, al mismo tiempo que se figura y transcribe el acto de la escritura y se incluyen las voces indígenas. La articulación de una multiplicidad de voces en un esquema jerárquico

\footnotetext{
${ }^{18}$ La Undécima Carta que informa sobre las acciones de los años 1618 y 1619 fue escrita por el Padre Pedro de Oñate e incluye una Carta del Padre Diego de Boroa. La Décima Carta que relata las acciones del año 1617 fue escrita por el Padre Pedro de Oñate e incluye otra del Padre Diego de Boroa.
} 
-expresión propia de un esquema de pensamiento- son aspectos de la dispositio argumentativa de esta narratio épica.

Y es que toda la acción evangelizadora se basa en la concepción particular del habitante autóctono. Los padres buscan exaltar "la dimensión espiritual del indígena." Veamos la designación reiterada en la sinécdoque que nombra al indígena con el término de la espiritualidad: alma: "las almas ciegas en su gentilismo y desamparo [...] La acción de los padres se caracteriza como una "[...] curación de las almas [...] para hacerlos salir el error en que viven [...]". Desde el punto de vista ético, en la sinécdoque esta el núcleo del mensaje. Frente a otros discursos que rebajan al hombre a su fisiología, a los órganos de la mitad de abajo del cuerpo, el discurso jesuita ante la dualidad físico-espiritual cuerpo/alma, jerarquiza el alma y eleva al indígena hacia un actuar espiritualmente.

\section{Referencias bibliográficas}

Beristain, Helena,1998, Diccionario de Retórica y Poética, México, Porrúa.

BouzI, Christian, 1993, "El emblema: un nuevo lugar estético para los antiguos lugares éticos", en Criticón, $\mathrm{N}^{\mathrm{o}}$ 58, Toulouse: Presses Universitaires du Mirail, 35-45

CÁtedra, Pedro,1994, Sermón y sociedad en la Edad Media. San Vicente Ferrer en Castilla (1411-1412), Valladolid, Junta de Castilla y León.

Cartas Anuas de la Provincia del Paraguay, Chile y Tucumán de la Compañía de Jesús -1615-1637, Ordenadas por el Padre Lehonardt para la colección dirigida por Emilio Ravignani, en Documentos para la Historia Argentina, Buenos Aires, Peuser, 1929, t. XX.

Cartas Anuas de la Provincia Jesuítica del Paraguay 1632-1634, Ordenadas por Ernesto J.A. Maeder, 1990, Buenos Aires, Academia Nacional de la Historia.

CERDAN, Francis,1993, "La emergencia del estilo culto en la oratoria sagrada del S.XVII”, en Criticón, No 58, Toulouse: Presses Universitaires du Mirail, 61- 72

CEDOMIL, Goic, 1984, Historia y Crítica de la Literatura Hispanoamericana, Madrid: Crítica, T. I.

CiCERÓN, Marco Tulio,1924, "Retórica a C. Herennio", en Obras Completas (Traducción de Marcelino Menéndez Pelayo), Madrid: Librería de los sucesores de Hernández. T. I

DEBAX, Michele, 1994, "Poesía y oralidad en los siglos de oro", en HOMMAGE À ROBERT JAMES, Toulouse: Presses Universitaires du Mirail, T. I, 313-320.

FERNÁNDEZ, Alberto Vicente,1987, Educación y palabra, Buenos Aires, Astrea.

FURLONG, Guillermo,1984, Los jesuitas y la cultura rioplatense, Buenos Aires: Universidad del Salvador 4.

GARDES DE FERnÁNDEZ, Roxana, 2001, Trayectorias simbólicas y Reducción. Un enfoque hermenéutico de las 'Cartas Anuas'- S.VII. (Proyecto de Investigación $\mathrm{UNaM})$. Inédito.

2002, "José Cardiel, Gonzalo de Doblas. Percepciones de América y heterogeneidad en el siglo XVIII", en LETRAS, 


\section{ROXANA GARDES DE FERNÁNDEZ}

Revista de la Facultad de Filosofía y Letras de la Pontificia Universidad Católica Argentina, No 44 (siglos XVIII y XIX), Buenos Aires, EDUCA.

, 2003, "La configuración de América. Escritura, mediación y distanciamiento", en Libro de Actas del Congreso Internacional: Políticas culturales e integración regional, Buenos Aires, Facultad de Filosofía y Letras, Instituto de Lingüística-UBA. Edición en CD.

2003, "Comparación y heurística: abducción o reducción” en Diálogos, ecos, paisajes, V Jornadas Nacionales, Buenos Aires, Asociación Argentina de Literatura Comparada, 326-333.

,2004, "Trayectoria simbólica y mediación cultural.

Las Cartas Anuas- Siglo XVII “, en Actas de las Jornadas de Literatura Colonial del Cono Sur, Buenos Aires, EDUCA.

, 2004, "Configuraciones de América en la trayectoria simbólica jesuítica. Cartas Anuas de la Provincia del ParaguaySiglo XVII", Relectura de las crónicas coloniales del cono sur, Buenos Aires, Universidad del Salvador, CONICET, 143-190.

2009, "El discurso de las Cartas Anuas de América,

Siglo XVII", en Boletín de la Academia Argentina de Letras. Buenos Aires. Tomo LXXIII, N²99-300, 1063-1107.

, 2011. "Retórica y Aisthesis en las Cartas Anuas de

América- Siglo XVII". En Actas del "ler Coloquio Nacional de Retórica" y "1 ras Jornadas Latinoamericanas de Investigación en Estudios Retóricos". Facultad de Filosofía y Letras. UBA. (En CD)

GRANADA, Luis de, 1945 “Los seis libros de la retórica eclesiástica o de la manera de predicar" en, Obras, Madrid, BAE, T. III

MAYORAL, José Antonio,1994, Figuras retóricas, Madrid: Síntesis.

OsORIO Romero, Ignacio, 1983, “La retórica en Nueva España, en Dispositio, Ann Arbor, Department of Romance Languages, University of Michigan, Vol. VIII, $\mathrm{N}^{\circ} \mathrm{s} 22-23,65-86$.

RALlo GRUS, Asunción, 1993, “Tópicos y recurrencias en los resortes del didactismo: confluencias de diferentes géneros, en Criticón, $\mathrm{N}^{\circ}$ 58, Toulouse: Presses Universitaires du Mirail, 135-154.

Quintiliano, Marco Fabio, 1944, Instituciones oratorias, Traducción de Ignacio Rodríguez y Pedro Sánchez, Buenos Aires, Joaquín Gil. 